\section{ANALISIS \\ MANAJEMEN BAZNAS \\ DALAM PENGENTASAN \\ KEMISKINAN}

Dalam buku ini yang menjadi permasalahan adalah pola manajemen zakat BAZNAS, faktor-faktor yang mempengaruhi pola manajemen zakat di BAZNAS dalam hal pengumpulan dan penyaluran zakat kepada mustahiq dan manajemen BAZNAS bila dihubungkan dengan maqashid al-Syariah zakat dalam pengentasan kemiskinan.

Tujuan pembahasan buku ini adalah untuk mengetahui dan mendeskripsikan pola manajemen zakat di BAZNAS, mengetahui dan mendeskripsikan faktor-faktor yang mempengaruhi pola manajemen zakat di BAZNAS dalam hal pengumpulan zakat dan penyaluran kepada mustahiq dan menganalisa hal-hal tersebut dengan tujuan zakat dari segi muzzaki dan mustahiq bila dihubungkan dengan maqashid al-syariah. Buku ini memberikan informasi yang lebih detail tentang bagaimana cara memahami konsep manajemen baznas dalam pengentasan kemiskinan secara lebih terstruktur. Sehingga buku ini sangat cocok bagi kalangan mahasiswa. Buku ini sangat jauh dari kesempurnaan maka dengan senang hati penulis menerima saran dan kritikan yang membangun dari pembaca.
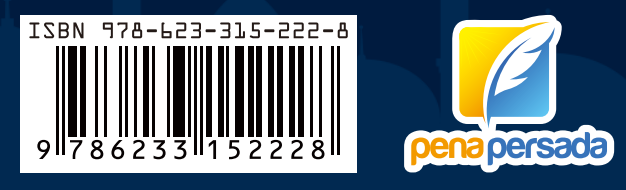

Anggi Aulia Desmarinda, S.E.Sy., M.H.

Nilfatri, S.E.I., M.H.

Gustina Martha, S.H., M.H.

\section{ANALISIS \\ MANAJEMEN BAZNAS \\ DALAM PENGENTASAN KEMISKINAN}

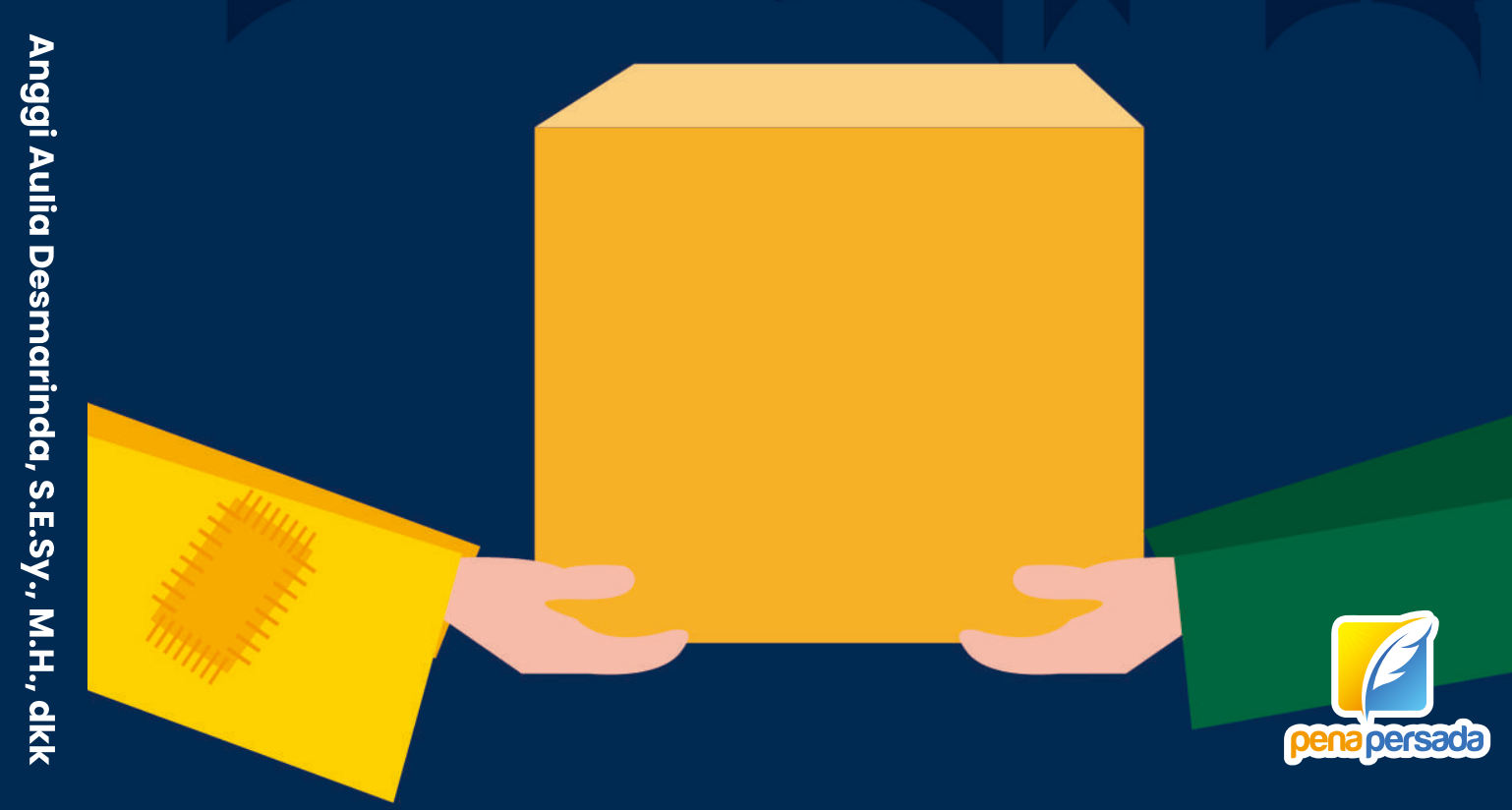




\title{
ANALISIS MANAJEMEN BAZNAS DALAM PENGENTASAN KEMISKINAN
}

\author{
ANGGI AULIA DESMARINDA, S.E.Sy., M.H \\ NILFATRI, S.E.I., M.H \\ GUSTINA MARTHA, S.H., M.H
}

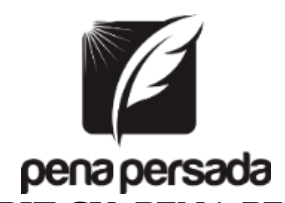

PENERBIT CV. PENA PERSADA 


\title{
ANALISIS MANAJEMEN BAZNAS \\ DALAM PENGENTASAN KEMISKINAN
}

\author{
Penulis: \\ Anggi Aulia Desmarinda, S.E.Sy., M.H \\ Nilfatri, S.E.I., M.H \\ Gustina Martha, S.H., M.H \\ ISBN : 978-623-315-222-8 \\ Editor: \\ Alisyah Pitri, M.Pd \\ Design Cover : \\ Retnani Nur Briliant \\ Layout : \\ Nisa Falahia \\ Penerbit CV. Pena Persada \\ Redaksi : \\ Jl. Gerilya No. 292 Purwokerto Selatan, Kab. Banyumas \\ Jawa Tengah \\ Email : penerbit.penapersada@gmail.com \\ Website : penapersada.com Phone : (0281) 7771388 \\ Anggota IKAPI \\ All right reserved \\ Cetakan pertama : 2021
}

Hak Cipta dilindungi oleh undang-undang. Dilarang memperbanyak karya tulis ini dalam bentuk apapun tanpa izin penerbit 


\section{KATA PENGANTAR}

Puji syukur saya panjatkan kepada Tuhan Yang Maha Esa, karena atas berkat dan rahmat-Nya, saya dapat menyelesaikan buku ini. Penulisan buku merupakan buah karya dari pemikiran penulis yang diberi judul "Analisis Manajemen BAZNAS Dalam Pengentasan Kemiskinan". Saya menyadari bahwa tanpa bantuan dan bimbingan dari berbagai pihak sangatlah sulit bagi saya untuk menyelesaikan karya ini. Oleh karena itu, saya mengucapkan banyak terima kasih pada semua pihak yang telah membantu penyusunan buku ini. Sehingga buku ini bisa hadir di hadapan pembaca.

Kajian dalam buku ini bertujuan untuk mengetahui dan mendeskripsikan faktor-faktor yang mempengaruhi pola manajemen zakat di BAZNAS dalam hal pengumpulan zakat dan penyaluran kepada mustahiq. Selanjutnya untuk menganalisa manajemen BAZNAS bila dihubungkan dengan maqashid alSyariah zakat dalam pengentasan kemiskinan.

Penulis menyadari bahwa buku ini masih jauh dari kesempurnaan. Oleh karena itu kritik dan saran yang membangun sangat dibutuhkan guna penyempurnaan buku ini. Akhir kata saya berharap Tuhan Yang Maha Esa berkenan membalas segala kebaikan semua pihak yang telah membantu. Semoga buku ini akan membawa manfaat bagi pengembangan ilmu hukum ekonnomi syariah. 


\section{DAFTAR ISI}

KATA PENGANTAR …...............................................................

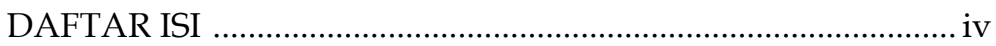

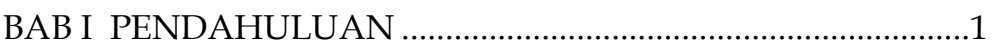

A. Persoalan Zakat............................................................1

B. Gambaran Umum BAZNAS Kab. Lima Puluh Kota ..........8

1. Sejarah BAZNAS Kab. Lima Puluh Kota.........................8

2. Landasan Hukum Pembentukan BAZNAS Kabupaten Lima Puluh Kota ...........................................10

3. Visi \& Misi Baznas Kab. Lima Puluh Kota ...................12

4. Struktur Organisasi BAZNAS Kab. Lima Puluh

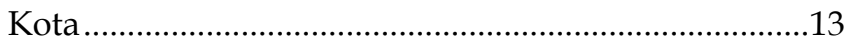

BAB II TEORI UMUM ZAKAT ....................................................17

A. Pengertian Zakat.................................................................

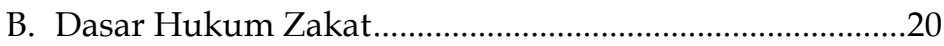

C. Golongan Penerima (Mustahik) Zakat ..............................22

D. Tujuan Pensyariatan Zakat ................................................29

E. Manajemen Zakat ....................................................................33

1. Definisi Manajemen...........................................................33

2. Manajemen Zakat ............................................................

3. Perencanaan Pengelolaan Zakat ......................................35

4. Pengorganisasian Pengelolaan Dana Zakat .................42

5. Pelaksanaan Pengelolaan Zakat.......................................44

6. Sistem Pengawasan dalam Pengelolaan Zakat ............47

BAB III ZAKAT PROFESI DAN MAQASHID AL-SYARIAH .49

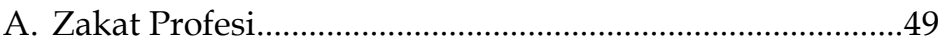

1. Pengertian Zakat Profesi................................................49

2. Dasar Hukum Zakat Profesi............................................52

3. Nishab, Waktu, Ukuran dan Cara Megeluarkan

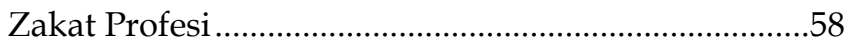

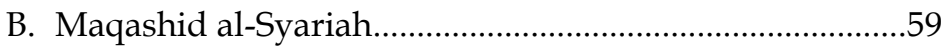

1. Pengertian Maqashid Al-Syariah..................................59

2. Kategori Dan Tertib Tujuan Hukum Syariah...............61 
BAB IV POLA MANAJEMEN ZAKAT DAN FAKTOR-

FAKTOR YANG MEMPENGARUHINYA ….............................. 74

A. Pola Manajemen Zakat di BAZNAS Kab. Lima Puluh Kota 74

1. Perencanaan Pengelolaan Zakat ................................... 74

2. Pelaksanaan Pengelolaan Zakat .................................... 79

3. Pengorganisasian Pengelolaan Dana Zakat................. 85

4. Pengawasan Pengelolaan Zakat.................................... 85

5. Faktor-faktor yang Mempengaruhi Pola Manajemen Zakat di BAZNAS Kab. Lima Puluh Kota ................... 87

B. Analisa Maqashid al-Syariah Manajemen BAZNAS Kab. Lima Puluh Kota dalam Pengentasan Kemiskinan......... 88

C. Maqashid al-Syariah Zakat untuk Pembangunan............. 100

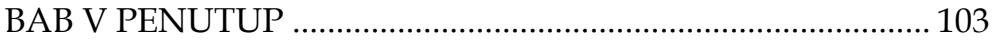

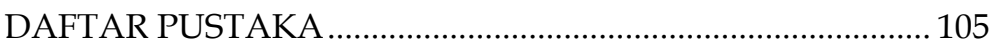

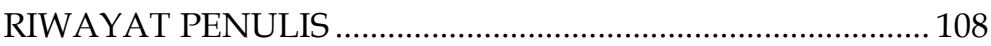




\section{ANALISIS MANAJEMEN BAZNAS \\ DALAM PENGENTASAN KEMISKINAN}




\section{BAB I \\ PENDAHULUAN}

\section{A. Persoalan Zakat}

Islam merupakan agama terakhir yang diturunkan oleh Allah swt kepada umat manusia lewat Nabi terakhir Muhammad saw. Sebagai agama terakhir, Islam memiliki beberapa aturan dan tata laksana yang harus diikuti oleh umatnya, baik yang sifatnya "melanjutkan" ajaran sebelumnya atau "membuat" ajaran baru. Salah satu ajaran Islam yang sifatnya "melanjutkan" tersebut adalah ibadah zakat. Namun demikian, zakat mempunyai posisi penting dalam Islam, bahkan zakat ini merupakan salah satu dari rukun Islam, di samping shalat, puasa dan haji.

Zakat juga merupakan bagian dari syari'at yang dibawa oleh para Rasul terdahulu. Karena itu, dapat dikatakan bahwa zakat sebagai ibadah yang menyangkut harta benda dan berfungsi sosial itu telah "berumur tua" karena telah dikenal dan diterapkan dalam agama samawi yang dibawa oleh para Rasul terdahulu. Hal ini dipahami dari beberapa ayat dalam Al-Qur'an, diantaranya: ${ }^{1}$

1. Surat al-A'raf: 156-157 yang mengisahkan Nabi Musa beserta kaumnya

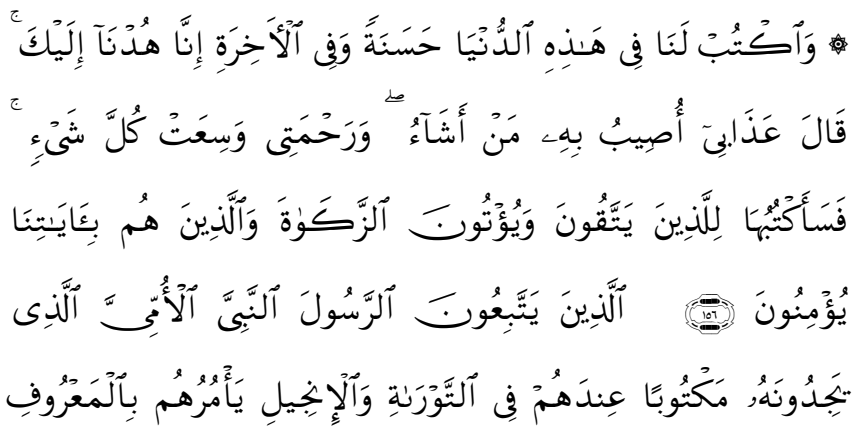

${ }^{1}$ Fakhruddin, Figh dan Manajemen Zakat di Indonesia, (Malang: UIN Malang Press, 2008), hal. 1-4 


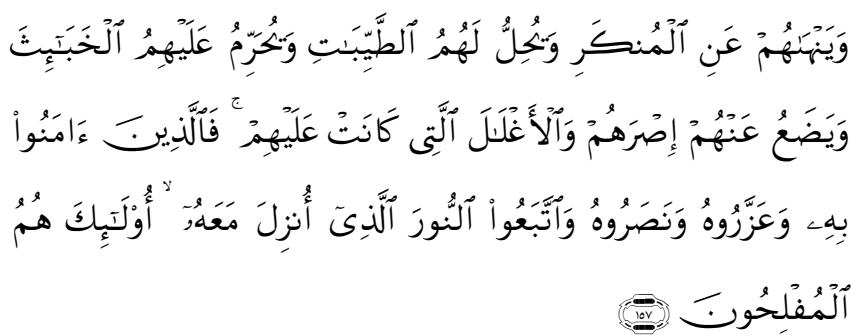

156. Dan tetapkanlah untuk Kami kebajikan di dunia ini dan di akhirat; Sesungguhnya Kami kembali (bertaubat) kepada Engkau. Allah berfirman: "SiksaKu akan Kutimpakan kepada siapa yang aku kehendaki dan rahmat-Ku meliputi segala sesuatu. Maka akan aku tetapkan rahmat-Ku untuk orangorang yang bertakwa, yang menunaikan zakat dan orang-orang yang beriman kepada ayat-ayat kami".

157. (yaitu) orang-orang yang mengikut rasul, Nabi yang Ummi yang (namanya) mereka dapati tertulis di dalam Taurat dan Injil yang ada di sisi mereka, yang menyuruh mereka mengerjakan yang ma'ruf dan melarang mereka dari mengerjakan yang mungkar dan menghalalkan bagi mereka segala yang baik dan mengharamkan bagi mereka segala yang buruk dan membuang dari mereka beban-beban dan belenggu-belenggu yang ada pada mereka. Maka orang-orang yang beriman kepadanya. memuliakannya, menolongnya dan mengikuti cahaya yang terang yang diturunkan kepadanya ( $\mathrm{Al}$ Quran), mereka Itulah orang-orang yang beruntung.

2. Surat al-Anbiya': 73 yang menceritakan kisah Nabi Ibrahim, Ishaq dan Ya'qub

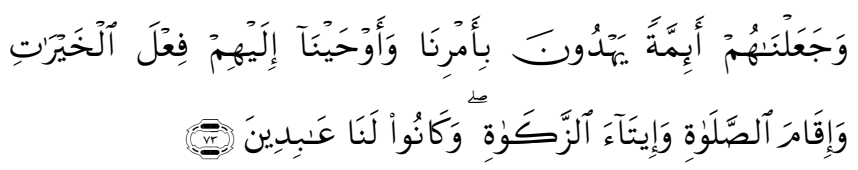

73. Kami telah menjadikan mereka itu sebagai pemimpinpemimpin yang memberi petunjuk dengan perintah Kami dan telah Kami wahyukan kepada, mereka 
mengerjakan kebajikan, mendirikan sembahyang, menunaikan zakat, dan hanya kepada kamilah mereka selalu menyembah"

3. Surat Maryam: 54-55 yang menceritakan tentang Nabi Ismail

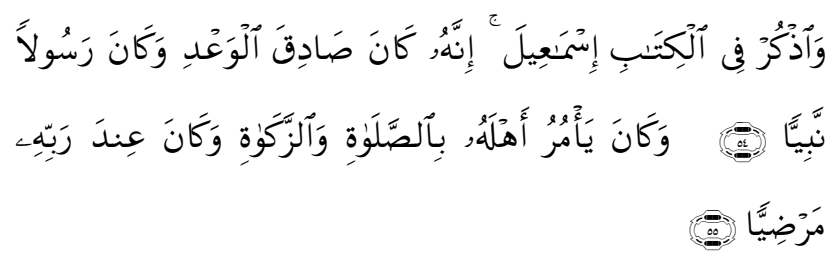

54. Dan Ceritakanlah (hai Muhammad kepada mereka) kisah Ismail (yang tersebut) di dalam Al Quran. Sesungguhnya ia adalah seorang yang benar janjinya, dan Dia adalah seorang Rasul dan Nabi.

55. Dan ia menyuruh ahlinya untuk bersembahyang dan menunaikan zakat, dan ia adalah seorang yang diridhai di sisi Tuhannya.

Berdasarkan keterangan ayat-ayat Al-Qur'an di atas, maka dapat diketahui dengan jelas bahwa walaupun ibadah zakat telah menjadi bagian dari syariat Rasul-rasul sebelum Nabi Muhammad saw, namun juga ajaran Nabi Muhammad yang merupakan kewajiban ibadah kepada Allah swt. Pada zaman Nabi, zakat belum dikumpulkan dan didistribusikan melalui lembaga formal selama masa awal di Makkah karena jumlah kaum muslim ketika itu relatif masih sedikit dan hidup dalam masyarakat yang memusuhi keyakinan mereka. Kaum muslimin mengeluarkan zakat secara pribadi untuk membantu orang-orang miskin dan untuk menebus kemerdekaan mereka yang dijadikan budak. ${ }^{2}$

Dalam Al-Qur'an zakat seringkali digandeng penyebutannya dengan shalat. Kata zakat dalam Al-Qur'an disebutkan secara makrifah sebanyak 30 kali. Delapan terdapat

${ }^{2}$ Abdullah al-Shiekh dalam Fakhruddin, Figh dan Manajemen..., hal. 6 
dalam surat Makiyah dan selainyya terdapat dalam surat Madaniyah. Penyebutan kata zakat yang bergandengan dengan kata shalat terdapat pada 28 tempat. ${ }^{3}$ Ini menunjukkan bahwa antara zakat dan shalat mempunyai kaitan yang sangat erat, meskipun terdapat perbedaan antara keduanya. Zakat adalah suatu ibadah maliyah yang lebih menjurus kepada aspek sosial kemasyarakatan (ijtima'iyah), untuk mengatur hubungan kehidupan manusia dan hubungannya dengan Allah swt, serta dalam hubungannya dengan sesama manusia. Sedangkan shalat lebih menjurus kepada pembentukan kepribadian yang mulia dan bersifat personal (fardiyah). Oleh karena itu, kewajiban mengeluarkan zakat ini sama dengan wajibnya kita melaksanakan shalat lima waktu. ${ }^{4}$

Menyadari tentang arti pentingnya zakat dalam menstabilkan perekonomian rakyat dan juga sesuai dengan tuntutan agama, maka di Indonesia saat ini telah dibentuk lembaga pengelola zakat yang dikenal dengan Badan Amil Zakat Nasional (BAZNAS) yang dibentuk oleh pemerintah dalam mengelola zakat secara nasional dan Lembaga Amil Zakat (LAZ) yang dibentuk oleh pihak swasta atau masyarakat yang bertugas membantu pengumpulan, pendistribusian dan pendayagunaan zakat.

Badan Amil Zakat Nasional (BAZNAS) adalah organisasi Pemerintah non struktural yang dibentuk oleh UndangUndang RI Nomor 23 Tahun 2011 tentang Pengelolaan Zakat. Dulu zakat secara berlembaga diurus secara Nasional Tahun 1973 - 1991 oleh YDSI (Yayasan Dana Sosial Islam).

Tugas Pokok YDSI ketika itu bukan hanya Zakat, Infak dan Shadaqah saja tetapi bermacam-macam kegiatan sosial. Penerimaan zakat dari Pegawai dan masyarakat kurang lancar. Hal ini disebabkan oleh timbulnya ketidakpercayaan masyarakat terhadap pendistribusian zakat yang tidak merata dan berkeadilan di setiap daerah. Dana zakat yang telah disetorkan Daerah ke Pusat hanya didistribusikan sebahagian

${ }^{3}$ Yusuf Qardawi, Fiqhu Zakat, (Beirut: Muasasah al-Risalah, 1991), hal. 42

${ }^{4}$ Fakhruddin, Figh dan Manajemen..., hal. 8 
besarnya untuk mustahiq di pusat. Tahun 1991 - 1999 Tugas YDSI diambil alih oleh BAZIS ( Badan Amil Zakat, Ifak dan Shadaqah ), sesuai dengan keputusan bersama Menteri Dalam Negeri dan Menteri Agama No 29 Tahun 1991 dan No 47 Tahun 1991, tentang BAZIZ secara nasional sampai ke daerah. Tahun 1999 - 2011 Nama BAZIS diganti BADAN AMIL ZAKAT ( BAZ ) sesuai dengan Undang-Undang Nomor 38 Tahun 1999 tentang Pengelolaan zakat. Tahun 2011 - sampai sekarang BAZ diganti dengan BAZNAS Sesuai dengan Undang-Undang Nomor 23 Tahun 2011 tentang Pengelolaan Zakat. ${ }^{5}$ Dalam rangka pelaksanaan pegelolaan zakat pada tingkat provinsi dan kabupaten/kota maka dibentuklah BAZNAS Provinsi dan BAZNAS Kabupaten Kota. ${ }^{6}$

Kabupaten Lima Puluh Kota merupakan salah satu daerah di Provinsi Sumatera Barat yang memiliki luas daerahnya 3.354.30 KM². Kabupaten Lima Puluh Kota memiliki wilayah yang cukup luas, yang terdiri dari Tiga Belas (13) Kecamatan. Rata-rata masih banyak ditemui Para mustahiq yang berada dalam situasi ekonomi yang sangat memprihatinkan.

BAZNAS Kab. Lima puluh Kota adalah lembaga zakat yang dibentuk oleh pemerintah setempat sesuai dengan spirit zakat melalui UU No 38 Tahun 1999. BAZNAS Kab. Lima Puluh Kota berdiri pada tahun 2004 berdasarkan Keputusan Bupati Lima Puluh Kota Nomor 235/BLK/2004 Tentang pembentukan Pengurus Badan Amil Zakat Daerah Periode 2004-2007. Tugas BAZNAS Kab Lima Puluh Kota itu sendiri adalah pengumpulan, pendistribusian dan pendayagunaan zakat. Zakat utama yang dikelola di BAZNAS Kab. Lima Puluh Kota adalah zakat profesi, yang tentu saja sasaran utamanya adalah para Pegawai Negri Sipil (PNS) di Kab. Lima Puluh Kota.

\footnotetext{
${ }^{5}$ Buku Panduan Rapat Kerja BAZNAS Tahun 2014

${ }^{6}$ UU No 23 Tahun 2011 tentang Pengelolaan Zakat
} 
Potensi zakat di Kab. Lima Puluh Kota adalah sebesar 8 Milyar setiap tahunnya. ${ }^{7}$ Namun, dari hasil wawancara penulis, bahwa di tahun 2015 BAZNAS Kab. Lima Puluh Kota baru berhasil mengumpulkan dana zakat sebesar Rp. 2.672.395.864, kemudian untuk tahun 2016 jumlah pengumpulan dana zakat di tahun berjalan adalah 1,449,645,448 per September $2016 .{ }^{8}$

Berikut tabel pengumpulan dan pendistribusian zakat dari tahun $2006 \mathrm{~s} / \mathrm{d}$ tahun 2016:

Tabel 1.1

\begin{tabular}{|c|c|c|c|}
\hline No & Tahun & Pengumpulan (Rp) & Pendistribusian (Rp) \\
\hline 1 & 2006 & $145,155,855$ & $93,250,000$ \\
\hline 2 & 2007 & $158,856,112$ & $138,050,000$ \\
\hline 3 & 2008 & $150,834,743$ & $133,450,000$ \\
\hline 4 & 2009 & $216,728,306$ & $220,400,000$ \\
\hline 5 & 2010 & $867,307,969$ & $662,000,000$ \\
\hline 6 & 2011 & $1,047,457,619$ & $880,500,000$ \\
\hline 7 & 2012 & $1,267,638,781$ & $1,115,500,000$ \\
\hline 8 & 2013 & $1,640,251,676$ & $1,510,475,000$ \\
\hline 9 & 2014 & $1,669,511,281$ & $1,394,700,000$ \\
\hline 10 & 2015 & $2,041,906,101$ & $2,366,683,000$ \\
\hline 11 & 2016 & $1,892,230,069$ & 1.863 .808 .000 \\
\hline \multicolumn{2}{|c|}{ Total } & $11,097,878,512$ & $10,378,816,000$ \\
\hline
\end{tabular}

Sumber: File Tabel pengumpulan dan pendistribusian BAZNAS Kab. Lima Puluh Kota 2006-2016

Kalau di lihat dari tabel di atas, pengumpulan jumlah zakat oleh BAZNAS Kab. Lima Puluh Kota bersifat fluktuatif setiap tahunnya. Angka ini tentu masih jauh dari target dan potensi yang ada di Kab. Lima Puluh Kota. Terlebih lagi jika

${ }^{7}$ Potensi zakat Pegawai Negri Sipil belum termasuk potensi dari pengusaha di Kab. Lima Puluh Kota

8 Wawancara dengan Jayusman, Ketua Umum BAZNAS Kab. Lima Puluh Kota, Kamis 24 November 2016 
dibandingkan dengan BAZNAS di daerah tetangga yaitu Kota Payakumbuh, dengan luas daerah $80,43 \mathrm{~km} 2$ dan hanya terdiri dari 5 kecamatan, BAZNAS Kota Payakumbuh di tahun 2015 berhasil mengumpulkan zakat sebesar Rp. 2.291.413.848 dan pada tahun 2016, berhasil mengumpulkan Rp. 2.530.213.972. ${ }^{9}$ Dari data-data tersebut terlihat bahwa dengan potensi dan luas daerah Kab. Lima Puluh Kota semestinya BAZNAS Kab. Lima Puluh Kota mampu memaksimalkan potensi yang ada. Zakat yang dikumpulkan oleh BAZNAS Kab. Lima Puluh Kota pada umumnya berupa zakat Pegawai Negeri Sipil, sedangkan zakat dari pengusaha, pedagang, petani, kontraktor dan profesional seperti dokter dan hakim belum sepenuhnya terkumpulkan oleh BAZNAS Kab. Lima Puluh Kota. Disini nampaknya sangat perlu upaya meningkatkan gerak BAZNAS Kab. Lima Puluh Kota ke arah yang lebih baik lagi untuk mencapai sasaran zakat itu sendiri dalam mengentaskan kemiskinan.

Jika dikaitkan dengan tujuan syariat atau maqashid alsyariah hal ini belum terwujud. Dimana hakikat maqashid alsyariah dari segi substansinya adalah kemaslahatan. Kemaslahatan dalam taklif Tuhan dapat berwujud dalam dua bentuk: pertama dalam bentuk hakiki, yakni manfaat langsung dalam arti kausalitas. Kedua, dalam bentuk majazi yakni bentuk yang merupakan sebab yang membawa kemaslahatan. Kemaslahatan yang dimaksud dapat dilihat pula dari dua sudut pandang yaitu maqashid al-Syari' (tujuan Tuhan) dan maqashid al-Mukallaf (tujuan Mukallaf). ${ }^{10}$

Salah satu maqashid al-Syariah zakat dalam pencapaian kemaslahatan adalah untuk mengentaskan kemiskinan sehingga terdapat pemenuhan kebutuhan hidup. Pendistribusian zakat di BAZNAS Kab. Lima Puluh Kota masih bersifat konsumtif saja. Sehingga sasaran utama zakat untuk mengubah status mustahiq menjadi muzzaki belum terpenuhi.

${ }^{9}$ Wawancara dengan Sovia Widya Putri, staff sekretariat BAZNAS Kota Payakumbuh, Kamis 24 November 2016

${ }^{10}$ Asafri Jaya Bakri, Konsep Maqashid Syari'ah Menurut al-Syatibi, (Jakarta: PT Raja Grafindo Persada, 1996), hal. 69 
Terlebih angka kemiskinan adalah 7,48\% ${ }^{11}$ dari jumlah penduduk Kab. Lima Puluh Kota sebesar 366.668 jiwa. Jika dikalkulasikan dalam angka, jumlah masyarakat miskin berdasarkan data tersebut adalah 27.426 jiwa.

\section{B. Gambaran Umum BAZNAS Kab. Lima Puluh Kota}

\section{Sejarah BAZNAS Kab. Lima Puluh Kota}

Badan Amil Zakat Nasional (BAZNAS) Kabupaten Lima Puluh Kota merupakan Lembaga Daerah Non Struktural yang diberi kewenangan untuk menghimpun, mengelola dan mengembangkan zakat, infaq dan shadaqh dengan tujuan untuk kemaslahatan umat khususnya di Kabupaten Lima Puluh Kota berdasarkan Syariat Islam dan Undang-Undang yang berlaku. Badan Amil Zakat Nasional (BAZNAS) Kabupaten Lima Puluh Kota dalam melaksanakan tugasnya bersifat independen sesuai dengan ketentuan Syariat, dan bertanggung jawab kepada Bupati dan BAZNAS Provinsi.

Badan Amil Zakat Nasional (BAZNAS) Kabupaten Lima Puluh Kota yang dulunya bernama Badan Amil Zakat Daerah (BAZDA) dibentuk berdasarkan surat keputusan Bupati Lima Puluh Kota Nomor 26 Tahun 2003 tentang Pengelolaan Zakat di Lima Puluh Kota. Sebagai realisasi pengelolaan Zakat tersebut, Tanggal 20 April 2004 Bupati akhirnya mengeluarkan surat keputusannya No. 235 tahun 2004 dan terbentuklah BAZDA Kabupaten Lima Puluh Kota dan tanggal 27 April 2004 pengurusnya langsung dilantik oleh Bupati.

Ibarat bayi yang baru lahir, Badan Amil Zakat Nasional (BAZNAS) Kabupaten Lima Puluh Kota mulai berdiri, melangkah dan berjalan. Tentunya tidak seperti orang yang sudah berjalan dan berlari cepat. Kerja keras dan semangat yang pantang menyerah, BAZNAS Lima Puluh Kota terus bersinergi dan berupaya mengadakan sosialisasi zakat. Setahun kemudian tepatnya tanggal 24 Oktober 2005

${ }^{11}$ Data Badan Pusat Statistik (BPS) Kab. Lima Puluh Kota Tahun 2014 
dengan surat edaran Bupati Lima Puluh Kota No. 946/491/BKD/2005 kepada PNS di Lima Puluh Kota diajak dan dihimbau untuk mengeluarkan zakat hasil profesinya ke BAZNAS Lima Puluh Kota. Lembaran pertama buku Kas/Bank mencatat penerimaan zakat dari PNS sebesar Rp. 4.823.100,-. Kemudian seiring dengan perjalan waktu, penerimaan zakat terus mengalami peningkatan, sehingga dalam jangka waktu lima bulan, BAZNAS Lima Puluh Kota mendistribusikan dana zakat perdananya kepada mustahiq sebesar Rp. 33.250.000,- pada tahun 2005 tersebut.

Kini sudah 11 tahun berjalan dengan fasilitas kantornya yang disediakan Kemenag Lima Puluh Kota dan hanya berukuran 3X3 M2, BAZNAS Lima Puluh Kota telah berhasil mengumpulkan dana zakat tahun 2015 sebesar Rp. 2.039.535.902,- (dua milyar tiga puluh Sembilan juta lima ratus tiga puluh lima ribu Sembilan ratus dua rupiah) dengan jumlah mustahiq yang telah diberi zakat sebanyak 3.591 orang mustahiq. Hal ini tidak terlepas dari peran serta dari Pemangku kebijakan di daerah Kabupaten Lima Puluh Kota. Pemerintah Kabupaten Lima Puluh Kota memberikan perhatian yang cukup besar terhadap pengelolaan zakat oleh Badan Amil Zakat Nasional (BAZNAS) Kabupaten Lima Puluh Kota. Diantara kontribusi Pemda adalah melalui dilahirkannya PERDA tentang Pengelolaan Zakat serta surat edaran dan pemberian Kendraan Roda Empat untuk kelancaran operasional lembaga dan juga Bantuan biaya operasional BAZNAS Kabupaten Lima Puluh Kota setiap tahun.

Tugas pokok dan fungsi Badan Amil Zakat Nasional (BAZNAS) Kabupaten Lima Puluh Kota adalah bertugas:

a. Melakukan pendataan muzakki, mustahiq, pengelolaan zakat, infak, dan shadaqah serta melakukan monitoring, evaluasi, pengendalian dan verifikasi terhadap lembaga zakat. 
b. Melakukan pengumpulan, penetapan jumlah zakat yang harus dipungut dan menyelenggarakan administrasi pembukuan dan pelaporan.

c. Melakukan pendistribusian/pendayagunaan zakat, infaq dan shadaqah.

d. Melakukan sosialisasi terhadap muzakki baik di lembaga maupun langsung kepada masyarakat dalam rangka menunaikan kewajiban zakat.

e. Menjalin kerja sama dengan Kemenag untuk mendayagunakan para penyuluh agama, ulama, umara, muzakki, dan mustahiq untuk pengembangan harta zakat.

f. Kedepan sebaiknya BAZ sudah mempunyai kantor yang representatif yang disiapkan oleh pemerintah.

g. Melakukan pengawasan terhadap penyaluran dan pengembangan serta pendayagunaan zakat oleh mustahiq.

h. Mendorong lembaga untuk diaudit baik auditor internal maupun auditor eksternal terhadap pengelolaan zakat. ${ }^{12}$

\section{Landasan Hukum Pembentukan BAZNAS Kabupaten Lima Puluh Kota}

Landasan Hukum pembentukan Badan Amil Zakat Nasional (BAZNAS) Kabupaten Lima Puluh Kota adalah:

a. Al Qur'an surat At Taubah ayat $60 \& 103$.

b. Dalam hadits Rasulullah menjelaskan sebagai berikut :

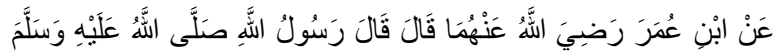

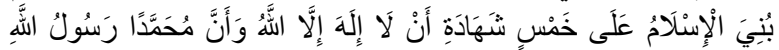

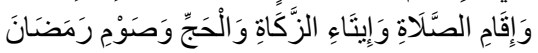

Dari Ibnu Umar Radhiyallahu 'anhuma, dia berkata: Rasulullah Shallallahu 'alaihi wa sallam bersabda: "Islam dibangun di atas lima (tonggak): Syahadat Laa ilaaha illa Allah dan (syahadat) Muhammad Rasulullah, menegakkan shalat, membayar zakat, hajji, dan puasa Ramadhan". [HR Bukhari, no. 8].

${ }^{12}$ File Gambaran Umum BAZNAS Kab. Lima Puluh Kota 


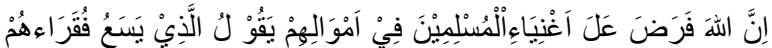

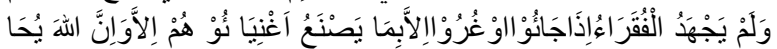

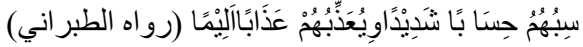

c. Undang-Undang Nomor 23 Tahun 2011 tentang Pengelolaan Zakat.

d. Peraturan Pemerin tah Nomor 14 Tahun 2014 tentang Pelaksanaan UU Nomor 23 Tahun 2011.

e. Instruksi Presiden Nomor 3 Tahun 2014 tentang Optimalisasi Pengumpulan Zakat di Kementerian/ Lembaga, Sekretariat Jenderal Lembaga Negara, Sekretariat Jenderal Komisi Negara, Pemerintahan Daerah, Badan Usaha Milik Negara, dan Badan Usaha Milik Daerah, melalui BAZNAS.

f. Keputusan Direktorat Jendral Bimbingan Masyarakat Islam Nomor DJ.II/568 Ttahun 2014 tentang Pembentukan BAZNAS Kupaten/Kota Se- Indonesia.

g. Peraturan BAZNAS No 01 Tahun 2014, tentang Pedoman Tta Cara Pengajuan Pengangkatan/Pemberhentian Pimpinan BAZNAS Provinsi, dan BAZNAS Kabupaten/ Kota.

h. Peraturan BAZNAS No 02 Tahun 2014, tentang Pedoman Tata Cara Pemberian Rekomendasi Izin Pembentukan Lembaga Amil Zzakat. 
i. Peraturan BAZNAS No 03 Tahun 2014 tentang Organisasi dan Tata Kerja BAZNAS Provinsi dan BAZNAS Kabupaten/Kota.

j. Keputusan Bupati Lima Puluh Kota No. 149 tahun 2015 tentang Perpanjangan Pengurus Badan Amil Zakat Nasional (BAZNAS) Kab. Lima Puluh Kota.

k. Surat Eedaran Bupati Lima Puluh Kota Nomor 113 Tahun 2014 tentang Optimalisasi Pengumpulan Zakat di Pemerintah Daerah Melalui BAZNAS Kab. Lima Puluh Kota. ${ }^{13}$

\section{Visi \& Misi Baznas Kab. Lima Puluh Kota}

a. Visi

“Terwujudnya Pengelolaan Zakat, Infaq dan Shadaqah

Yang Amanah, Profesional dan Transparan Yang Bergerak Dalam Mengumpulkan, Mendistribusikan serta Menumbuh Kembangkan Dana Umat Islam Untuk Pemberdayaan Kaum Dhu'afa".

b. Misi

1) Menjadikan BAZNAS Kab. Lima Puluh Kota dalam mendukung program pemerintah mengentaskan kemiskinan untuk pemberdayaan kaum lemah;

2) Menjadikan BAZNAS sebagai satu-satunya lembaga tempat menyalurkan zakat, infaq dan shadaqah bagi umat Islam;

3) Menjadikan BAZNAS sebagai lembaga yang amanah, profesional, transparan dalam mengelola dana umat Islam;

4) BAZNAS sebagai sebagai fasilitator, dinamisator dalam pemberdayaan kaum dhu'afa;

5) Menjadikan BAZNAS sebagai jembatan emas menuju ladang amal dengan Ikhlas dan jujur serta mengharap Ridho Allah SWT.

${ }^{13}$ File Gambaran Umum BAZNAS Kab. Lima Puluh Kota 
Sebagai penjabaran dari Visi dan Misi di atas, maka BAZNAS Kabupaten Lima Puluh Kota bertekad mewujudkan :

1) Lima Puluh Kota Religi;

2) Lima Puluh Kota Sejahtera;

3) Lima Puluh Kota Cerdas;

4) Lima Puluh Kota Sehat;

5) Lima Puluh Kota Peduli. ${ }^{14}$

\section{Struktur Organisasi BAZNAS Kab. Lima Puluh Kota}

Dengan telah diberlakukannya Undang-Undang Nomor 23 Tahun 2011 tentang Pengelolaan Zakat dan pelaksanaannya diatur dalam Peraturan Pemerintah Nomor 14 Tahun 2014, maka struktur kepengurusan organisasi BAZNAS berubah sesuai dengan PP tersebut. Hal itu telah disikapi oleh Kementerian Agama Kabupaten Lima Puluh Kota untuk dilakukan Pembentukan struktur kepengurusan yang baru. Sampai saat ini rangkaian pembentukan kepengurusan Badan Amil Zakat Nasional (BAZNAS) Kabupaten Lima Puluh Kota yang baru masih sedang berjalan. Maka untuk legalitas dan kewenangan dalam pengelolaan Zakat di Lima Puluh Kota. Bupati Lima Puluh Kota telah menerbitkan Surat Keputusan Nomor 149 tanggal 19 Maret 2015 tentang Pengukuhan Perpanjangan Kepengurusan Badan Amil Zakat Nasional Kabupaten Lima Puluh Kota Periode 2012-2015. secara legalitas struktur organisasi Badan Pelaksana dan Sekretariat BAZNAS Kabupaten Lima Puluh Kota terdiri dari :

${ }^{14}$ File Gambaran Umum BAZNAS Kab. Lima Puluh Kota 